OPEN ACCESS

Volume: 9

Special Issue: 1

Month: May

Year: 2021

E-ISSN: 2582-1334

Received: 28.04.2021

Accepted: 05.05.2021

Published: 10.05.2021

Citation:

Can, Fatih. "Examining the Relationship Between Turkish Teacher Candidates' Metacognitive Learning Strategies and Critical Listening Attitudes." Shanlax International Journal of Education, vol. 9, no. S1, 2021, pp. 145-153.

DOI:

https://doi.org/10.34293/ education.v9iS1-May.4010

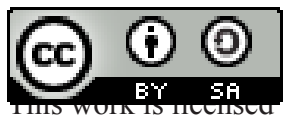

under a Creative Commons Attribution-ShareAlike 4.0 International License

\section{Examining the Relationship Between Turkish Teacher Candidates' Metacognitive Learning Strategies and Critical Listening Attitudes}

\author{
Fatih Can
}

Amasya University, Turkey

(D) https://orcid.org/0000-0002-9593-2382

\begin{abstract}
This study aims at examining the relationship between Turkish teacher candidates' metacognitive learning strategies and critical listening attitudes as well as determining whether theircritical listening attitudes and the use of metacognitive learning strategies vary with gender, age, year in college, and grade point average (GPA). Accordingly, a correlational survey design was used. The sample of the study consists of 191 Turkish teacher candidates studying at the Turkish teacher education program of Amasya University, Faculty of Education. The Metacognitive Learning Strategies Determining Scale developed by Gündoğan Çöğenli \& Güven (Bilişüstü...) and the Critical Listening Attitude Scale developed by Taşkn were used as data collection tools. The data were analyzed using statistical package software SPSS 22.0. T-test, ANOVA, and correlation analysis were performed. A positive correlation was determined between Turkish teacher candidates' critical listening behaviors and the use of metacognitive learning strategies. We believe that the findings of this study will contribute to determining critical listening attitudes.
\end{abstract}

Keywords: Turkish teacher candidates, Metacognitive learning strategies, Critical listening, Correlational survey

\section{Introduction}

In general, learning can be defined as the process of gaining divergent knowledge, experience, manners, and skills that enable the individual to continue and enjoy his life in his environment (Sönmez and Durmaz 127; Taşdemir 118; Yılmaz 175). For complete learning, just getting information is not enough, but also making permanent changes in skills, behaviors, and attitudes through processing this information in the mind is needed (Güneş, 3; Kaya and Akdemir, 110). It is very important for an individual to take responsibility for his/her own cognition and learning, manage his/her learning process, and develop self-learning strategies. The term metacognitive refers to an individual's awareness of his/her cognition and learning abilities (Baltac1 and Akpinar 320). Metacognitive was first introduced by Flavel and is an important concept related to learning (Pehlivan and Şahin 174).

Metacognition is essentially about the processes related to managing one's awareness and process information through his/her thinking mechanism (Efklides 76). Accordingly, metacognition and cognition are different terms, since metacognition is about the processes after or beyond a task but cognition is about the awareness to perform that task (Schrawas cited in Aktürk 23).

An individual performs some conscious mental operations during learning (Melanlıoğlu Metacognitive... 70). In this case, individuals with the knowledge of strategy understand where and how to use information, how to direct the problem-solving process, how to react according to the outcome, and what kind of responsibility they will take in the learning process (Özsoy 27-28). 
Accordingly, one chooses the learning environment, uses time effectively, identifies his/ her goals, makes plans, and monitors him/herself, thus carries out self-evaluation (Baykara 81). Language skills are essential for learning and thus play important role in this regard. Listening is the main stage of learning. "So, it would not be wrong to say that listening skills have an important role in one's life. In this sense, it is very critical to achieve listening skills during the learning process."(Demir 134). One's correct perception of the environment and life and the adaptation to the social environment depends on gaining the habit of listening during the education process (Kemiksiz 300).

Besides being the first language skill acquired, listening is also important in terms of social norms (Fidan 80). As a listening skill, critical listening provides great support toan individual in both his/ her social life and also the education period. The critical listener reaches a judgment and conclusion by analytically evaluating what he/she has heard. In this regard, a critical listener will not immediately agree with what he/she has heard (Akdemir 73; Çarkıt 183).Therefore, critical listening poses a higher demand for listeners (Akdemir and Takkaç 1805; Li, Gao and Zhang 57).

Considering the above-mentioned importance of critical thinking habits and metacognitive learning strategies, the current paper tries to identify the relationship between Turkish teacher candidates' metacognitive learning strategies and critical listening attitudes. To the best of our knowledge,there are no similar studies. However, according to a literature survey, a study conducted by Gündoğan Çöğenli (Class...) determining primary school teachers' metacognitive learning strategies can be mentioned here as a study about metacognitive learning strategies. In a similar study, Güçlü examined science teacher candidates' learning strategies. Furthermore, Kana (... Metacognitive...) examined Turkish teacher candidates'levels of metacognitive awareness and Kana (...Motivational...) investigated Turkish teacher candidates' cognitive and metacognitive competencies. Additionally, Baykara Özaydınlık conducted a study to examine teacher candidates' metacognitive learning strategies. Besides, regarding the relevant literature, a study conducted by Şahin determining Turkish teacher candidates' listening types, Ürün Karahan examined Turkish teacher candidates' listening styles, Karadüz investigated Turkish and primary teacher candidates' listening strategies. Furthermore, Şenşekerci and Kartal examined primary teacher candidates' critical thinking tendencies and Polat and Kontaş examined the same tendency in primary teachers. Moreover, a study conducted by Kazu and Demiralp examined primary teachers' critical listening competencies.

Today, technology is advancing and changing rapidly. So, in the beginning, individuals need some information, plans, and strategies regarding how learning will take place. The current paper is considered important since it determines the use of metacognitive learning strategies and critical listening attitudes of Turkish teacher candidates studying at Turkish teacher education programs at a college of education, providing a detailed picture of Turkish teacher candidates' current condition and making divergent recommendations. Considering the previous studies, the present study can make a valuable contribution to the literature due to the limited number of studies examining similar situations.

This study aims at examining the relationship between metacognitive learning strategies and critical listening attitudes of Turkish teacher candidates studying at the Turkish teacher education program of Amasya University, Faculty of Education in the 2020/2021 academic year and to determine whether metacognitive learning strategies and critical listening attitudes vary according to particular variables. In this context, answers will be sought to the following questions:

1. Do Turkish teacher candidates' metacognitive learning strategies and critical listening attitudes significantly vary by gender, age, year in college, grade point average?

2. What is the relationship between metacognitive learning strategies and critical listening attitudes of Turkish teacher candidates?

\section{Method \\ Research Design}

Since the purpose of this paper is to determine the relationship between metacognitive learning 
strategies and critical listening behaviors of Turkish teacher candidates through particular variables, a correlational survey design was used. According to Karasar, correlational survey design aims to identify whether two or more variables work together and the nature of the difference, if any.

\section{Population and Sample}

The population of this study consists of Turkish teacher candidates studying at Turkish teacher education programs of the state colleges in Turkey of education. The sample consists of 191 Turkish teacher candidates studying at the Turkish teacher education program of Amasya University, Faculty of Education. The convenience sampling method was used to select participants. According to Ekiz, convenience sampling allows the researcher to obtain the sample group and participants easily. The sample consists of first, second, third and fourth-year college students studying at the Turkish teacher education program.

\section{Data Collection}

To determine Turkish teacher candidates' metacognitive learning strategies, The Metacognitive Learning Strategies Determining Scale developed by Gündoğan Çöğenli and Güven (Metacognitive...) was used. This was a 5-point Likert-type scale with 28 items. The validity and reliability studies of the scale were previously conducted by Gündoğan Çöğenli and Güven (Metacognitive...). In that study,
Cronbach's alpha coefficient was found as .87 (Gündoğan Çöğenli and Güven).In the current study, Cronbach's alpha coefficient was calculated as .91.

To examine the Turkish teacher candidates' critical listening behaviors, The Critical Listening Attitude Scale including 20 items developed by Taşkınwas used. The internal consistency reliability (Cronbach's alpha coefficient) was found by Taşkın as .81. In the present study, Cronbach's alpha coefficient was calculated as .71. According to a general accepted rule, an internal consistency reliability above 0.70 indicates an acceptable level of reliability (McMillan and Schumacher). Accordingly, both scales used in this study had high reliabilities. The participants were responded to the questionnaires through Google Forms.

\section{Analysis of Data}

The collected data were analyzed using statistical package software SPSS 22.0. While the positive items were scored as 5, 4, 3, 2, 1; the negative items were reverse scored $1,2,3,4,5$. Since the homogeneity tests showed that the data set was homogeneous, parametric tests were preferred. Accordingly, t-test and analysis of variance (ANOVA) tests were performed and post-hoc tests were used to identify significant differences between groups. Furthermore, correlation analysis was conducted to determine the level of correlation between metacognitive learning strategies and critical listening attitudes of Turkish teacher candidates.

\section{Findings}

Table 1 Result of the t-test for Metacognitive Learning Strategies and Critical Listening Attitudes by Gender

\begin{tabular}{|c|c|c|c|c|c|c|}
\hline & Gender & N & Mean & sd & t & p \\
\hline \multirow{2}{*}{ Critical Listening } & Female & 133 & 3,8970 &, 27701 & &, 787 \\
\cline { 2 - 7 } & Male & 58 & 3,8828 &, 35523 &, 271 & \\
\hline \multirow{2}{*}{ Metacognitive Learning Strategies } & Female & 133 & 4,2884 &, 39275 & &, 028 \\
\cline { 2 - 7 } & Male & 58 & 4,1453 &, 41617 & 2,222 & \\
\hline
\end{tabular}

As seen in Table 1, the $t$ value belongs to the difference between Turkish teacher candidates' metacognitive learning strategies and critical listening behavior scores was not significant $(\mathrm{t}=.271$, $\mathrm{p}>0.05$ ). However, a significant difference was found among metacognitive learning strategy scores with gender $(\mathrm{t}=2.222, \mathrm{p}<0.05)$. Accordingly, it was observed that female teacher candidates display higher metacognitive learning strategies than males. 
Table 2 Mean and Standard Deviation Scores for Metacognitive Learning Strategies and Critical Listening Attitudes by Age

\begin{tabular}{|c|c|c|c|c|}
\hline & Age & N & Mean & sd \\
\hline \multirow{4}{*}{ Critical Listening } & $17-19$ & 44 & 3,8807 &, 29732 \\
\cline { 2 - 5 } & $20-22$ & 129 & 3,8895 &, 30655 \\
\cline { 2 - 5 } & $23-25$ & 7 & 3,8214 &, 27058 \\
\cline { 2 - 5 } & 26 and over & 11 & 4,0227 &, 28841 \\
\hline \multirow{3}{*}{ Metacognitive Learning Strategies } & $17-19$ & 44 & 4,3628 &, 44865 \\
\cline { 2 - 5 } & $20-22$ & 129 & 4,2038 &, 38029 \\
\cline { 2 - 5 } & $23-25$ & 7 & 4,2449 &, 67115 \\
\cline { 2 - 5 } & 26 and over & 11 & 4,2565 &, 18953 \\
\hline
\end{tabular}

As shown in Table 2, participants aged 26 and while the highest mean score was observed in teacher over had the highest mean score for critical listening candidates aged 17-19, the lowest mean score was behavior. On the other hand, the lowest mean obtained in the age group of 20-22. The mean scores score was obtained in participants aged 23 to 25 . were similar among different age groups. Regarding the metacognitive learning strategies,

Table 3 The Results of ANOVA for Metacognitive Learning Strategies and Critical Listening Attitudes Scores by Age

\begin{tabular}{|c|c|c|c|c|c|c|}
\hline & & Sum of squares & df & Mean square & $\mathbf{F}$ & $\mathbf{p}$ \\
\hline \multirow{3}{*}{ Critical Listening } & Between groups & 229 & 3 & 076 & 835 &, 476 \\
\hline & Within groups & 17,101 & 187 & ,091 & & \\
\hline & Total & 17,330 & 190 & & & \\
\hline \multirow{3}{*}{$\begin{array}{c}\text { Metacognitive } \\
\text { Learning Strategies }\end{array}$} & Between groups &, 832 & 3 & ,277 & 1,715 &, 165 \\
\hline & Within groups & 30,229 & 187 & , 162 & & \\
\hline & Total & 31,060 & 190 & & & \\
\hline
\end{tabular}

According to Table 3, no significant differences these results, it can be argued that teacher candidates' were found in teacher candidates' critical listening critical listening scores and metacognitive learning $\operatorname{scores}(\mathrm{F}=.835 ; \mathrm{p}>0.05)$ and metacognitive learning strategy scores do not differ with age. strategy scores $(\mathrm{F}=1.715 ; \mathrm{p}>0.05)$ by age. Based on

Table 4 Mean and Standard Deviation Scores for Metacognitive Learning Strategies and Critical Listening Attitudes by Year in College

\begin{tabular}{|l|c|c|c|c|}
\hline & Year & N & Mean & sd \\
\hline \multirow{3}{*}{ Critical Listening } & 1 & 55 & 3,9055 &, 32923 \\
\cline { 2 - 5 } & 2 & 53 & 3,8387 &, 27485 \\
\cline { 2 - 5 } & 3 & 55 & 3,9136 &, 27813 \\
\cline { 2 - 5 } & 4 & 28 & 3,9286 &, 34141 \\
\hline \multirow{4}{*}{ Metacognitive Learning Strategies } & 1 & 55 & 4,3481 &, 32923 \\
\cline { 2 - 5 } & 2 & 53 & 4,1058 &, 27485 \\
\cline { 2 - 5 } & 3 & 55 & 4,2539 &, 27813 \\
\cline { 2 - 5 } & 4 & 28 & 4,2883 &, 34141 \\
\hline
\end{tabular}


As seen in Table 4, the highest critical listening mean score was observed in fourth-year college students. On the other hand, the lowest mean score belongs to second-year teacher candidates.

Table 5 Variance Analysis of Metacognitive Learning Strategies and Critical Listening Attitudes Scores by Year in College

\begin{tabular}{|c|c|c|c|c|c|c|}
\hline & & Sum of squares & df & Mean square & F & p \\
\hline \multirow{2}{*}{ Critical Listening } & Between groups &, 224 & 3 &, 075 &, 815 &, 487 \\
\cline { 2 - 7 } & Within groups & 17,106 & 187 &, 091 & & \\
\hline & Total & 17,330 & 190 & & & \\
\hline $\begin{array}{c}\text { Metacognitive } \\
\text { Learning Strategies }\end{array}$ & Between groups & 1,668 & 3 &, 556 & 3,537 &, 016 \\
\cline { 2 - 7 } & Within groups & 29,392 & 187 &, 157 & & $1-2$ \\
\hline & Total & 31,060 & 190 & & & \\
\hline
\end{tabular}

As shown in Table5, no significant differences were found in critical listening attitudes scores of teacher candidates by year in college $(\mathrm{F}=.815$; $\mathrm{p}>0.05$ ). On the other hand, it was observed that scores for metacognitive learning strategy vary

significantly by year in college $(\mathrm{F}=3.537 ; \mathrm{p}<0.05)$. The Post-Hoc test showed that significant difference exists between first and second-year college students' scores.

Table 6 Mean and Standard Deviation Scores for Metacognitive Learning Strategies and Critical Listening Attitudes by Grade Point Average

\begin{tabular}{|l|c|c|c|c|}
\hline \multirow{4}{*}{ Critical Listening } & Grade Point Average & N & Mean & sd \\
\hline \multirow{4}{*}{ Metacognitive Learning Strategies } & $0.00-2.00$ & 8 & 3,9375 &, 44139 \\
\cline { 2 - 5 } & $2.00-2.50$ & 40 & 3,9138 &, 35337 \\
\cline { 2 - 5 } & $2.51-3.00$ & 82 & 3,8811 &, 27840 \\
\cline { 2 - 5 } & $3.01-3.50$ & 58 & 3,8897 &, 28125 \\
\cline { 2 - 5 } & $3.51-4.00$ & 3 & 3,8667 &, 36171 \\
\cline { 2 - 5 } & $0.00-2.00$ & 8 & 4,3616 &, 38296 \\
\cline { 2 - 5 } & $2.00-2.50$ & 40 & 4,2205 &, 50306 \\
\cline { 2 - 5 } & $2.51-3.00$ & 82 & 4,2496 &, 37156 \\
\hline \multirow{4}{*}{} & $3.01-3.50$ & 58 & 4,2211 &, 38159 \\
\hline
\end{tabular}

According to Table 6, the highest critical listening mean score was observed in teacher candidates with a grade point average (GPA) of between $0.00-2.00$ (for the 4.0 scale). On the other hand, students with a GPA between $3.51-4.00$ had the lowest critical listening mean score. Regarding metacognitive learning strategies, while the highest mean score was determined in college students who hada GPA between $3.51-4.00$, the lowest mean score was observed in those with a GPA between $2.00-2.50$. However, the score differences among groups were very small.

Table 7 The Results of ANOVA for Metacognitive Learning Strategies and Critical Listening Attitudes Scores by GPA

\begin{tabular}{|c|c|c|c|c|c|c|}
\hline & & Sum of squares & df & Mean square & F & p \\
\hline \multirow{2}{*}{ Critical Listening } & Between groups &, 047 & 4 &, 012 &, 128 &, 972 \\
\cline { 2 - 7 } & Within groups & 17,282 & 186 &, 093 & & \\
\hline
\end{tabular}


2021 Papers in Education: Current Research and Practice

\begin{tabular}{|c|c|c|c|c|c|c|}
\hline & Total & 17,330 & 190 & & & \\
\hline \multirow{2}{*}{$\begin{array}{c}\text { Metacognitive } \\
\text { Learning Strategies }\end{array}$} & Between groups &, 536 & 4 &, 134 &, 816 &, 516 \\
\cline { 2 - 7 } & Within groups & 30,525 & 186 &, 164 & & \\
\hline & Total & 31,060 & 190 & & & \\
\hline
\end{tabular}

As seen in Table7, no significant differences were found in teacher candidates' critical listening behaviors $(\mathrm{F}=.128 ; \mathrm{p}>0.05)$ and metacognitive learning strategies scores $(\mathrm{F}=.816 ; \mathrm{p}>0.05)$ according to their GPA. Based on these results, it can be argued

that the GPA of students had no significant effect on their critical listening attitudes and metacognitive learning strategies.

Table 8 Results of Correlation Analysis on the Relationship between Metacognitive Learning Strategies and Critical Listening Attitudes

\begin{tabular}{|c|c|c|c|c|}
\hline & \multicolumn{2}{|c|}{ Critical Listening } & \multicolumn{2}{c|}{ Metacognitive Learning Strategies } \\
\hline Critical Listening & $\mathrm{r}$ & - & &, $542^{* *}$ \\
\hline Metacognitive Learning Strategies & $\mathrm{r}$ &, $542^{* *}$ & & - \\
\hline$* * . \mathrm{p}<0.01$
\end{tabular}

According to Table 8, the correlation value between Turkish teacher candidates' critical listening attitudes and metacognitive learning strategies scores was calculated as .542 , statistically significant at the 0.05 level. This finding indicates a positive correlation between critical listening behaviors and metacognitive learning strategies. Accordingly, it can be argued that as critical listening scores increase, the use of metacognitive learning strategies increases.

\section{Discussion and Conclusion}

The current paper aims to determine the relationship between Turkish teacher candidates' metacognitive learning strategies and critical listening attitudes. The results of the t-test examining whether gender related differences exist in the Turkish teacher candidates' metacognitive learning strategies showed that a statistically significant difference exists between male and female participants, in favor of females. Consistent with our findings, Kana (...Motivational...) found that Turkish female teacher candidates exhibit higher metacognitive competencies compared to males. Similarly, Kana (...Metacognitive...) observed that Turkish female teacher candidates had higher metacognitive awareness than male teacher candidates. Furthermore, Özaydınlık reported that female teacher candidates had higher levels of metacognitive learning strategies than male teacher candidates. Moreover, Gündoğan Çöğenli (Class...) found that female and male teacher candidates' level of use of metacognitive learning strategies were not different, similarly, the study conducted by Güçlü showed that female and male science teacher candidates' level of use of metacognitive learning strategies did not vary. Previous studies on this subject have indicated that female participants'level of use of metacognitive learning strategies is higher than males. In a study conducted by Şahin, no significant difference was found between female and male Turkish teacher candidates' listening styles on screen.

The variance analysis conducted to determine whether Turkish teacher candidates' critical listening attitudes and metacognitive learning strategies differ with gender showed that no gender differences. A study carried out by Ürün Karahan examining Turkish teacher candidates' listening styles, no differences were found in Turkish teacher candidates' listening styles with year in college.

According to the variance analysis performed to determine whether Turkish teacher candidates' critical listening behaviors and metacognitive learning strategies vary with year in college, metacognitive learning strategies significantly vary with year in college and this difference exists between first and second-year teacher education students. Kana (...Motivational...) found that male and female Turkish teacher candidates had similar metacognitive competencies. On the other hand, the study conducted by Güçlü showed that second and third-year science teacher education students' 
level of use of metacognitive learning strategies was higher than others. Moreover, Şahin conducted a study to determine Turkish teacher candidates' listening styles and did not found a difference in listening styles according to year in college.

The variance analysis performed to determine whether participants' critical listening attitudes and metacognitive learning strategies vary with their GPA indicated that no significant differences exist. On the other hand, Kana (...Motivational...) reported that Turkish teacher candidates who had a GPA of 2.50 or higher exhibited higher metacognitive competencies.

Listening skills have an important impact on the development of thinking. In this regard, one's listening skills are closely related to his/her thinking behaviors because all we have heard are recorded by one's own words and interpretation. So, listening also increases thinking operations (İzin as cited in Melanlığlu 73). There is an important relationship between thinking and listening. Therefore, it can be argued that the critical listening attitudes of the participant Turkish teacher candidates were closely related to their thinking behaviors. Furthermore, in a similar study conducted by Şenşekerci and Kartal examining primary school teacher candidates' critical listening competencies, it was found that primary school teacher candidates had low critical listening behaviors and competencies. Moreover, a study examining primary school teacher candidates' critical listening attitudes conducted by Polat and Kontaşrevealed that primary school teacher candidates had low critical listening performances.

A correlation analysis was applied to determine the correlation level between participants'critical listening and the use of metacognitive learning strategies scoresand a positive correlation was found. Thus, it can be said that critical listening attitudes and metacognitive learning strategies increase together.As metacognitive learning strategies increase, academic success increase. Accordingly, education on metacognitive learning strategies would play a critical role in increasing teacher candidates' performance and competencies (Akdemir 128; Baykara Özaydınlık 140). In this regard, metacognitive learning strategies education emerges as an important subject that should be considered in higher education.

The following recommendations can be made based on the results obtained in the current study:

- Long-term applied research can be conducted to examine critical listening attitudes and in-depth resultscan be achieved.

- Studies at the higher education level examining the contribution of critical listening to teachers, particularly Turkish teachers can be conducted. In this regard, in addition to prospective teachers, research can be done on current teachers and the scope of research can be expanded by comparing similarities and differences between teacher candidates and existing teachers.

- To show the possible contributions of the use of metacognitive learning strategies in education to both teacher professions and also to personality development, more comprehensive studies can be conducted at the higher education level with different participants to examine students from different faculties and programs in addition to teacher education students in faculties of education.

- Since critical listening is one of the key skills required in the teaching profession, performing similar studies with different programs of faculties of education could provide a valuable contribution to the literature by showing the differences among departments.

- The current study was conducted with teacher candidates studying at Amasya University, faculty of education. However, the samplecan be expanded by conducting studies in different faculties of education in Turkey with more teacher candidates and faculties of education can be compared in terms of geographical regions.

- Further studies can be conducted examining the pedagogical benefits of using metacognitive learning strategies and critical listening skills to teachers. Accordingly, contributions to the teacher profession can be made.

\section{References}

Akdemir, Ahmet Selçuk, and Mehmet Takkaç. "Extraversion and Female EFL Learners as Listeners A Qualitative Investigation." Universal Journal of Educational Research, vol. 4, no. 8, 2016, pp. 1802-1808.

Akdemir, Ahmet Selçuk. "Age Gender Attitudes and Motivation as Predictors of Willingness to Listen in L2." Advances in Language and 
Literary Studies (ALLS), vol. 10, no. 4, 2019, pp. 72-79.

Akdemir, Ahmet Selçuk. "The Development and Validation of Willingness to Listen in L2 WTL Scale." PASAA: Journal of Language Teaching and Learning in Thailand, vol. 51, 2016, pp. 127-154.

Aktürk, Ahmet Oğuz. Bilgisayar Dersinde Üstbiliş Ögretim Stratejilerinin Etkisi. Selçuk Üniversitesi, 2010.

Baltac1, Mesut, and Burhan Akpınar. "The Effect of Web Based Instruction on the Metacognition Awareness Levels of Learners." Mustafa Kemal University Journal of Social Sciences Institute, vol. 8, no. 16, 2011, pp. 319-333.

Baykara Özaydınlık, Kevser. "A Comparative Analysis of Preservice Teachers' Metacognitive Learning Strategies and Teacher Self-Efficacy Perceptions." $H$. U. Journal of Education, vol. 33, no. 1, 2018, pp. 125-143.

Baykara, Kevser. "A Study on "Teacher Efficacy Perceptions" and "Metacognitive Learning Strategies" of Prospective Teachers." H.U. Journal of Education, vol. 40, no. 40, 2011, pp. 80-92.

Çarkıt, Cafer. "The Importance and Place of Critical Listening/Monitoring in Turkish Education." RumeliDE Dil ve Edebiyat Araştırmalart Dergisi, vol. 16, 2019, pp. 180-193.

Demir, Özden. "An Investigation of the Prospective Teachers' level of using Cognitive Awareness Skills while Studying: A Qualitative Study." Hacettepe Üniversitesi Eğitim Fakültesi Dergisi, vol. 44, no. 44, 2013, pp. 133-148.

Efklides, Anastasia. "The Role of Metacognitive Experiences in the Learning Process." Psicothema, vol. 21, no. 1, 2009. pp. 76-82.

Ekiz, Durmuş. Bilimsel Araştırma Yöntemleri. Anı Publishing, 2009.

Fidan, Mehmet. "Examination of Critical Listening Strategies in Turkish Lessons of Secondary School Students in Terms of Various Variables." RumeliDE Journal of Language and Literature Studies, no. 15, 2019, pp. 79-98.

Güçlü, Gamze. Fen Bilgisi Öğretmen Adaylarının Ögrenme Stilleri ve Bilişüstü Ö̆rrenme Stratejilerinin Incelenmesi, Frat Üniversitesi,
2020.

Gündoğan Çöğenli, Aslı. Sınıf Öğretmenlerinin Sahip Olduklart Öğrenme Stilleri ve Kullandıkları Bilişüstü Ögrenme Stratejileri. Anadolu Üniversitesi, 2011.

Gündoğan Çöğenli, Aslı and Güven, Meral. "Validity and Reliability of Metacognitive Learning Strategies Determining Scale." Dicle Üniversitesi Ziya Gökalp Eğitim Fakültesi Dergisi, no. 22, 2014, pp. 283-297.

Güneş, Firdevs. "Okuma ve Sınırsız Öğrenme." Sınırsız Eğitim ve Araştırma Dergisi, vol. 2, no. 1, 2017, pp. 1-20.

Kana, Fatih. "Motivational, Cognitive And Metacognitive Competences of Preservice Turkish Language Teachers." Uluslararası Eğitim Bilimleri Dergisi, no. 4, 2015, pp. 395-407.

Kana, Fatih "Metacognitive Awareness Levels of Turkish Language Preservice Teachers." Akademik Sosyal Araştırmalar Dergisi, no. 17, 2015, pp. 66-81.

Karadüz, Adnan. "The Evaluation of Listening Strategies of Turkish Language and Primary Student Teachers." Erciyes Üniversitesi Sosyal Bilimler Enstitüsü Dergisi, vol. 1, no. 29, 2010, pp. 39-55.

Karasar, Niyazi. Bilimsel araştırma yöntemleri. Nobel Akademik Yayıncılık, 2011.

Kazu, Hilal, and Demiralp, Demet. "Comparison of Critical Listening Proficiency of Teacher Candidates in terms of Several Variables." Eurasian Journal of Educational Research, no. 68,2017 , pp. 81-95.

Kemiksiz, Ömer. "Critical Listening in Turkish Education." Erzincan Üniversitesi Sosyal Bilimler Enstitüsü Dergisi, vol. 9, no. 2, 2015, pp. 299-316.

Li, Yingxia et al. "To Speak Like a TED Speaker - A Case Study of TED Motivated English Public Speaking Study in EFL Teaching." Higher Education Studies, vol. 6, no. 1, 2016, pp. 53-59.

Mcmillan, James H., and Sally Schumacher. Research in Education: Evidence-Based Inquiry. Pearson, 2010.

Melanlığlu, Deniz. Üstbiliş Stratejileri Eğitiminin Ilköğretim Ikinci Kademe Öğrencilerinin Dinleme Becerilerine Etkisi, Gazi 
Üniversitesi, 2011.

Melanlığlu, Deniz "Dinleme Becerisinin Geliştirilmesinde Ailenin Rolü." Sosyal Politika Çalışmaları Dergisi, vol. 7, no. 29, 2012, pp. 65-77.

Özsoy, Gökhan. İlköğretim Beşinci Sınıfta Üstbiliş Stratejileri Öğretiminin Problem Çözme Başarısına Etkisi. Gazi Üniversitesi, 2007.

Pehlivan, Elif and Fatma Şahin. "Effect of Case Study Method on Academic Achievement, Remembering and Metacognitive Skills With Regard to "A Voyage To Inner Structure of The Living Thing Unit of Science Lesson." Marmara Üniversitesi Atatürk Eğitim Fakültesi Eğitim Bilimleri Dergisi, no. 25, 2007, pp. 171-184.

Polat, Musa and Hakkı Kontaş. "Examining Primary School Teachers' Critical Thinking Disposition." Elektronik Sosyal Bilimler Dergisi, vol. 17, no. 65, 2018, pp. 142-159.

Sönmez, Görsev, and Büşranur Durmaz. "Relationship among Efficacy, Strategy Use and Proficiency: Case of Listening in an EFL Classroom." Turkish Online Journal of English Language Teaching (TOJELT), vol. 2, no. 3, 2017, pp. 120-129.

Şahin, Harun. "Investigation of Listening Types of Turkish Pre-service Teachers in terms of the Various Variables: A Case of Kafkas University." Journal of Language and Linguistic Studies, vol. 16, no. 1, 2020, pp. 306-315.

Şenşekerci, Erkan and Hülya Kartal. "Pre-Service Teachers' Critical Thinking Tendencies." e-Journal of New World Sciences Academy, vol. 5, no. 3, 2010, pp. 839-857.

Taşdemir, Muhammed Salih. "The Effect of Visual Support on Listening Comprehension in Turkish Elementary EFL Learners." Turkish Online Journal of English Language Teaching (TOJELT), vol. 3, no. 3, 2018, pp. 111-28.

Taşkın, Yusuf. "Critical Listening Attitude Scale's Validity and Reliability Study for Prospective Teachers." International Journal of Language Academy, vol. 5/2, 2017, pp. 116-128.

Ürün Karahan, Berna. "Examination of the Listening Styles of Turkish Teacher Candidates in Terms of Various Variables (Case of Kafkas University)." e-Kafkas Ĕgitim Araştırmaları Dergisi, vol. 3. no. 3, 2016, pp. 9-25.

Yılmaz, Malik. “Öğrenme ve Bilgi İlişkisi.” Journal of Gazi Educational Faculty (GUJGEF), vol. 29, no. 1, 2009, pp. 173-190.

\section{Author Details}

Fatih Can, Amasya University, Turkey, Email ID: fatihcan.fatih@hotmail.com. 